\title{
Úlcera eosinófila de la mucosa oral
}

\author{
Eosinophilic ulcer of oral mucosa
}

\author{
A.C. Bencini'. C.A. Bencini², V. Strada 3 , M. Florencia Soldavini ${ }^{4}$, G.M. Bruno 4 , M.F. Cordeu ${ }^{4}$, \\ M.A. Cotignola 4
}

Resumen: La Úlcera Eosinófila de la Mucosa Oral, es una entidad poco frecuente, pobremente descrita en la literatura mundial. Se define como una lesión benigna autolimitada que si bien puede presentarse en distintas áreas de la cavidad bucal, presenta una marcada predilección por la mucosa ventral de la lengua. Clínicamente, se presenta como una lesión ulcerada de bordes indurados y sobreelevados. Los hallazgos histopatológicos son característicos y consisten en un infiltrado mixto rico en eosinófilos, acompañado de una población de grandes células mononucleadas. Recientes artículos basados en estudios inmunohistoquimicos, permiten afirmar la presencia de grandes linfocitos atípicos CD30+ y por lo tanto, incluir esta lesión en el espectro de las entidades simuladoras de desordenes linfoproliferativos.

A pesar de esto, el mecanismo etiopatogenico permanece oscuro y el trauma local juega un rol todavía no dilucidado; aunque se halla presente en la mayoría de las publicaciones, explicando el fenómeno como un mecanismo reactivo. La importancia de esta lesión, radica en su diagnostico diferencial por su semejanza clínica al carcinoma espinocelular, histoplasmosis, chancro sifilítico, Úlcera tuberculosa, carcinoma epidermoide y otras.

En nuestro trabajo se revisa la literatura y se discuten la características clínicas, histopatológicas y alternativas terapéuticas, a partir del artículo de un caso clínico en una paciente joven, que luego de la biopsia escisión como método para el diagnostico de certeza, se produce una recidiva de la lesión; lo que orientó el tratamiento hacia la cirugía combinada con corticoterapia local intralesional, logrando su remisión.

Palabras clave: Terceros molares; Colgajo lineal; Colgajo triangular; Edema; Trismus; Dolor.

Recibido: 04.06.2007

Aceptado: 15.10 .2008

1 Cirujano Bucomaxilofacial. Presidente Electo de la Sociedad Argentina de Cirugía y Traumatología Bucomaxilofacial. Encargado del área de Cirugía Bucomaxilofacial en el H.I.E.A. y C. San Juan de Dios de la Plata, Argentina. Miembro de la SACyTBMF; ALACIBU; SECOM; IAOMS.

2 Cirujano Bucomaxilofacial. Prof. Titular de Cirugía B Facultad de Odontología de la Universidad Nacional de La Plata, Argentina. Prof. Consulto en Cirugía BMF del Servicio de Odontología y Cirugía Bucomaxilofacial del H.I.E.A. y C. San Juan de Dios de la Plata, Argentina. Miembro de la SACyTBMF; ALACIBU; SECOM; IAOMS.

3 Médica patóloga - H.I.E.A. y C. San Juan de Dios de la Plata, Argentina.

4 Miembros del Servicio de Odontología y Cirugía Bucomaxilofacial del H.I.E.A. y C. San Juan de Dios de la Plata, Argentina.
Abstract: Eosinophilic Ulcer of the Oral Mucosa, an entity, poorly deciphers in world-wide literature. It is defined as a self-limited, benign injury that although it can appear in different areas of the buccal cavity it presents a noticeable predilection via the ventral mucosa of the tongue. Clinically, one looks like an ulcer with hard and risen edges. The histo-pathological findings are typical and consist of a rich infiltrated mix of eosinophils, as well as a population of large mononuclear cells. Recent reports based on immunohistochemical studies allow us to confirm the presence of large atypical lymphocytes CD30+ and therefore include this lesion injury in the spectrum of lympho proliferative disorder simulators. Despite this the etiopathogenic mechanism remains unknown and local trauma still plays an unexplained roll; although the majority of publications have explained the phenomena as a reactive mechanism. The importance of this injury is established by its differential diagnostic because of its clinical similarity to Spinocellular Carcinoma, Histoplasmosis, syphilitic chancre, Ulcer Tuberculosis, Epidermoid Carcinoma and others. In our work the literature is reviewed and clinical characteristics, histo-pathologies and alternative therapies are discussed. We use the case of a young patient who has a biopsy in an effort to diagnose with certainty has a relapse of the lesion which directs the treatment towards combined surgery and local intra lesion cortico therapy which led to successful remission.

Key words: Ulcer; Eosinophils; Lympho proliferative disorders; Differential diagnostic.

\section{Correspondencia:}

Prof. Dr. Adrián Carlos Bencini

Diagonal 74 no 2571 entre 20 y 21

CP1900 La Plata. Buenos Aires. Argentina

Tel/fax: 542214511859

e-mail: adrianbencini@speedy.com.ar 


\section{Introducción}

La palabra úlcera es utilizada para definir "la pérdida de sustancia de evolución crónica, que afecta el corion y no cicatriza."(Grinspan, D.; 1975).

La Úlcera Eosinófila de la Mucosa Oral (UEMO), es una entidad benigna, infrecuente, caracterizada por ulceras únicas o múltiples, de bordes elevados e indurados, sin eosinofilia en sangre. Es poco descripta en la literatura y a lo largo del tiempo ha recibido distintas denominaciones como xantoendotelioma, xantoma juvenil, xantogranuloma, granuloma eosinofilo diutium de la lengua y finalmente, úlcera Eosinófila de la mucosa oral.

En la publicación de la Revista de la Sociedad Argentina de Dermatología del año 2002,1 se incluye a la úlcera eosinófila de la mucosa oral dentro de la clasificación de Fitzpatrick (Tabla 1), de enfermedades eosinófilas cutáneas, en el grupo 1 donde los eosinófilos forman parte del patrón diagnostico-histológico, subgrupo $1 \mathrm{~b}$, caracterizado por eosinofilia tisular.

Puede aparecer en cualquier grupo etario, sin distinción de sexo y su localización más frecuente es la mucosa de la lengua.

La mayoría de los autores, coinciden en que su etiopatogenia es traumática como plantean en 1964, Baskar y Lilly, 2,3 o que por lo menos, el factor traumático seria determinante en el daño tisular. De hecho, esta entidad fue descrita en primera instancia en 1881, por un medico italiano, Antonio Riga, ${ }^{3}$ y los estudios histológicos con los casos fueron publicados por F. Fede en 1890; de allí que se llamo enfermedad de Riga-Fede. Esta patología es la expresión de la úlcera eosinófila de la mucosa oral en los niños, provocada por el trauma de los movimientos de succión sobre los incisivos inferiores, en la lactancia.

Otros, proponen un mecanismo mas complejo de inmunidad mediada por linfocitos $\mathrm{T}$.

Recientemente, gracias a las técnicas de inmunohistoquímica se ha podido demostrar que al menos en algunos casos, existe una proliferación de linfocitos T CD30 positivos, que puede ser clonal o no; incluyendo a la UEMO en el espectro de los desordenes linfoproliferativos. ${ }^{6}$ Pero ciertamente, la etiología es desconocida aún.

Dentro de las patologías que presentan una úlcera como lesión elemental, en la cavidad bucal, se puede realizar el diagnóstico diferencial con carcinoma espinocelular, sífilis, úlcera traumática, tuberculosis, histoplamosis y otras. $8,9,11$

\section{Introduction}

The word ulcer is used to define "the loss of chronic evolution substance that affects the dermis and doesn't scar" (Grinspan, D.; 1975).

Eosinophilic Ulcer of the Oral Mucosa is an infrequent, benign entity characterized by one or many ulcers whose borders are elevated and hardened without eosinophil in the blood. It is not described very much in the literature and over time it has receive various denominations like xantoendotheliome, juvenile xantoma, xanthogranulome, granulome eosinophylic diutium of the tongue and finally eosinophilic ulcer of the oral mucosa. In the 2002 edition of the Argentinean Dermatologists Society magazine the eosinophilic ulcer of the oral mucosa was included in the Fitzpatrick classification (Table I), of eosinophil skin illnesses. It was included in group 1 where eosinophils form part of a histological diagnostic pattern, subgroup $1 b$ which is characterized by eosinophile tissue.

It could appear in any etary group, with sex distinction and usually appearing on the mucous membrane of the tongue.

In 1964 Baskar and Lilly, 2,3 established that etiopathology is traumatic and the majority of authors agree, or at least they agree that the trauma would be a determining factor in tissue damage. In fact, this entity was first described in 1881 by an Italian doctor named Antonio Riga. ${ }^{3}$ Histological cases were published in 1890 by F. Fede hence the illness is named Riga-Fede. This pathology is the expression of Eosinophil Ulcer of the Oral Mucosa in children, caused by the trauma of suction over the inferior incisors and lactation.

Others propose a more complex immunity mechanism measured by T lymphocytes.

Recently, thanks to immunohistochemistry techniques it has been possible to show that, at least in some cases, there are proliferations of lymphocytes $T C D 30+$, which can be clonal or not; including EUOM in the spectrum of lymph pro- 


\section{Material y método}

En agosto de 2005, se presentó al Servicio de Odontología y Cirugía Bucomaxilofacial del Hospital Interzonal Especializado en Agudos y Crónicos San Juan de Dios de La Plata, Buenos Aires, Argentina; una paciente de sexo femenino, de 13 años de edad, 53 kilos de peso, contextura mediana, procedente de la localidad de Madariaga, interior de la provincia de Buenos Aires, con una lesión ulcerada en la lengua de cuatro meses de evolución, detectada por la paciente.

La paciente no presenta antecedentes personales ni familiares de enfermedad alguna. Manifiesta que hace aproximadamente 4 meses detecto una lesión en la lengua (sin observarla en otra parte del cuerpo), por la que concurrió a la consulta con diferentes médicos y odontólogos quienes en varias ocasiones, medicaron con colutorios antisépticos, antivirales (en crema y comprimidos), corticoides por vía oral, antimicóticos, sin lograr una remisión completa en ninguno de los casos.

A la inspección clínica se observa una úlcera en la cara ventral de la lengua de aproximadamente $1,5 \times 2 \mathrm{~cm}$, de bordes sobreelevados, eritematosos, no hemorrágica y de fondo blanquecino (Fig. 1). A la palpación sus bordes son indurados, no así el centro de la lesión. La úlcera se presenta móvil y sin adherencia en profundidad. La paciente no manifiesta dolor espontáneo ni a la palpación. No se perciben adenopatías locales ni regionales. No se observan anomalías dentarias, ni bordes incisales filosos en las piezas anteroinferiores, con oclusión clase I de Angle. Los estudios de laboratorio se encuentran sin particularidades, salvo una eritrosedimentacion de $46 \mathrm{~mm}$ en la primera hora (método de Westergreen).

\section{Tratamiento}

Bajo premedicacion (amoxicilina + ácido clavulánico 2 g, 1 h. antes) y anestesia local (carticaina $4 \%$ ) se realiza biopsia escisión circunscribiendo la lesión (Figs. 2 y 3). Se envía la muestra operatoria a estudio anatomopatológico, solicitando estudio micológico y viral para descartar etiología micótica o viral; cuyos informes mostraron resultados negativos. Mientras que el diagnostico anatomopatológico es: úlcera eosinófila de lengua.

\section{Evolución}

A las 4 semanas del postoperatorio la paciente presenta recidiva de la lesión, de mucho menor tamaño que la lesión primaria (Fig. detected 4 months prior. The patient did not have a family history of any illnesses. 4 months prior she noticed a lesion on her tongue (without noticing anything else on her body) for which other doctors prescribed antiseptic mouthwash, antiviral medicine (cream and pill form), oral corticoids, and atimycotics, none of which resulted in complete remission.

Upon clinical inspection an ulcer measuring $1.5 \times 2 \mathrm{~cm}$ was observed on the ventral face of the tongue. The ulcer had over elevated borders, erythematous, was not hemorrhagic and was whitish in color (Fig. 1). Upon palpation its borders were hard but the centre of the lesion was not. The ulcer seems to be mobile and not deeply adhered. The patient doesn't report spontaneous pain even during the palpation. Neither local nor regional adenopathies were detected. We did not observe dental irregularities or sharp borders of anteroinferior teeth, with class 1 occlusion of Angle.

The results of the laboratory studies showed no abnormalities except on erytho sedimentation of $46 \mathrm{~mm}$ in the first hour (Westergreen Method).

\section{Treatment}

The patient was given amoxicillin and $2 \mathrm{~g}$ of clavulanic acid one hour before surgery and was operated on under local anesthetic (carticaine 4\%). A biopsy was performed encompassing the lesion (Figs. 2 and 3). The sample was 


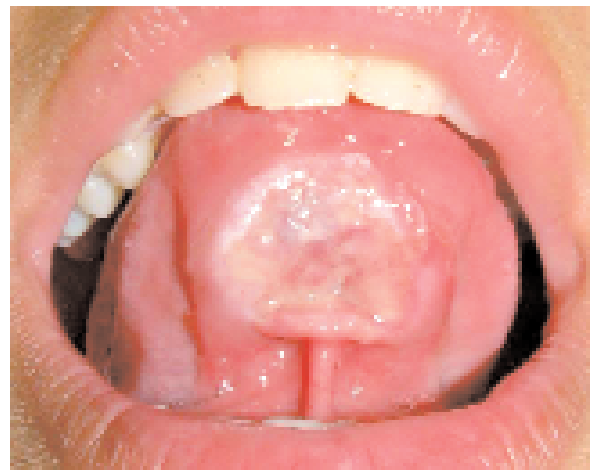

Figura 1. Úlcera Eosinófila. Figure 1. Eosinophilia Ulcer.

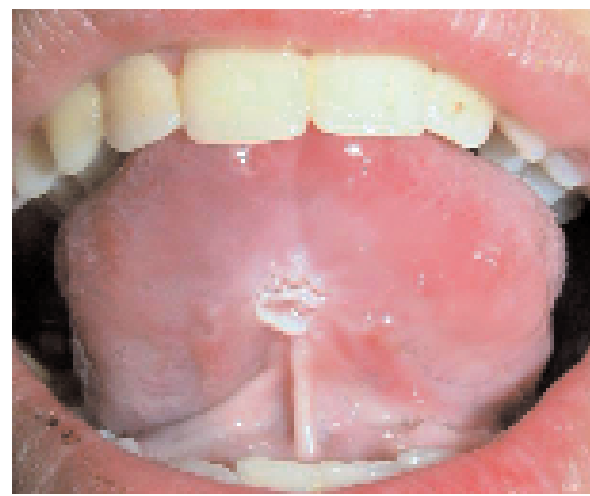

Figura 4. 1ำ recidiva a los 28 días. Figure 4. $1^{\text {st }}$ relapse after 28 days.

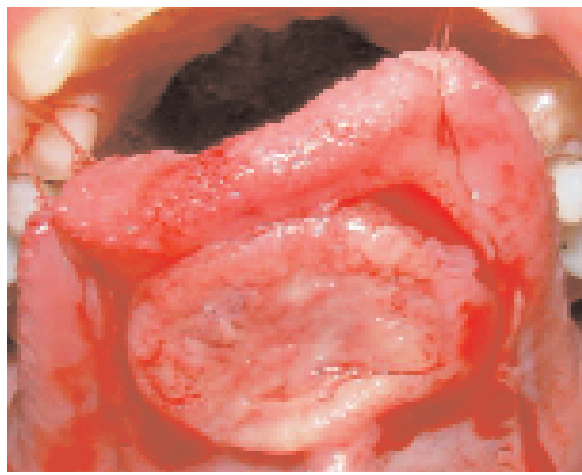

Figura 2. Biopsia escisión. Figure 2. Abscission Biopsy.

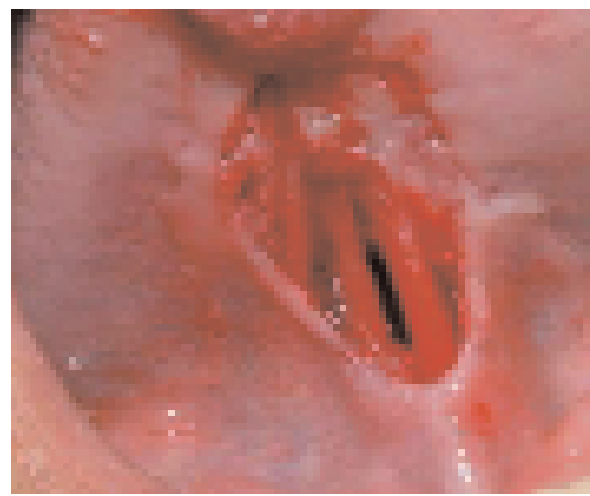

Figura 5. 2o Biopsia escisión. Figure 5. $2^{\text {nd }}$ absiccion biopsy.

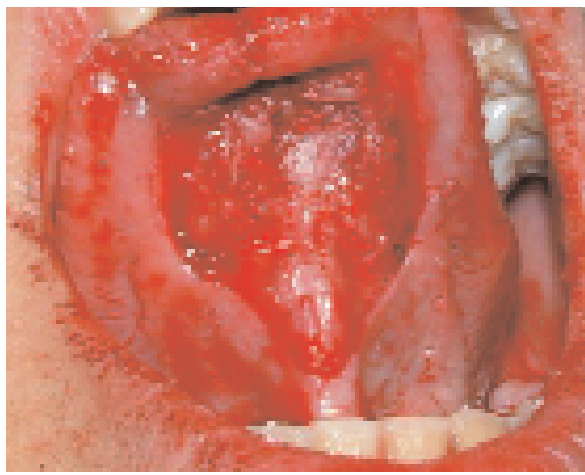

Figura 3. Lecho quirúrgico. Figure 3. Surgical bed.

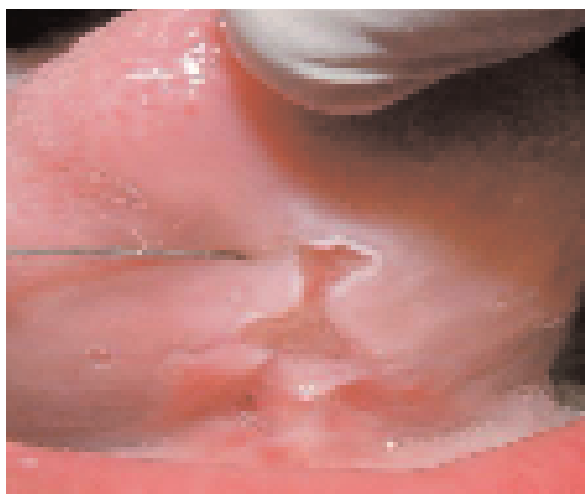

Figura 6. 2 o recidiva Corticoterapia intralesional Figure 6. $2^{\text {nd }}$ relapse intralesional corticotherapy.
4), por lo que se indica una nueva biopsia escisional, pero en esta ocasión se divulciona en un plano más profundo (Fig. 5) para eliminar la rabdomiositis producida por los eosinófilos (Med Cutan Iber Lat Am 2003;31:213-4); la cual ratifica el diagnóstico de úlcera eosinófila. A los 21 dias de esta ultima intervención, muestra una nueva recidiva. Por tal motivo se decide realizar corticoterapia intralesional, submucosa preferentemente, con Acetato de Betametasona $3 \mathrm{mg} / \mathrm{ml}$-Fosfato disódico de Betametasona 3,9 mg/ml a la dosis de $1 \mathrm{ml}$ más $1 \mathrm{ml}$ de carticaína $4 \%$ por $\mathrm{cm}^{2}$ que abarque la lesión, cada 7 días (Fig. 6); obteniendo una excelente respuesta a la terapéutica. La lesión se redujo en casi un $75 \%$ en la segunda semana (Fig. 7); con una remisión completa de la lesión a los 45 días de la primera infiltración (Fig. 8).

\section{Discusión}

La úlcera eosinófila de la mucosa oral es motivo de controversia entre patólogos, dermatólogos, clínicos y cirujanos a la hora de establecer su etiología y tratamiento

La lesión consiste en un proceso inflamatorio benigno y poco frecuente, caracterizado por una ulceración única de bordes netos, a veces indolora, ubicada en la cara ventral de la lengua en el mayor porcentaje de los casos.

Muchos autores asignan a esta entidad una etiología netamente traumática, y afirman que seria la expresión en adultos de lo que sent to be anatomic pathologically studied, asking for a mycological and viral study in order to rule out mycotic or viral etiologies. The results of these tests were negative. The anatomic pathological diagnosis is Eosinophil Tongue Ulcer.

\section{Progress}

Four months after surgery the lesion relapsed. The relapse lesion is much smaller than the first one (Fig. 4), so another scission biopsy is performed but this time involves a deeper area in order to eliminate the rhabdomyositis produced by the eosinophils (Med Cutan Iber Lat Am 2003; 31:213-4). This act confirms the Eosinophil Ulcer diagnosis. 21 days after the 2 nd intervention another relapse is found so intra lesion cortico therapy is carried out, rather sub mucosa, with betamethasone acetate $3 \mathrm{mg} / \mathrm{ml}$ Disodic Betamethosone phosphate $3.9 \mathrm{mg} / \mathrm{ml}$ of the dosis of 1 $\mathrm{ml}$ plus I $\mathrm{ml}$ of carticain $4 \%$ per $\mathrm{cm} 2$ including the lesion every 7 days (Fig. 6); excellent therapeutic results were found.

The lesion reduced in size by $75 \%$ by the second week with complete remission of the lesion after 45 days (Fig. 8).

\section{Discussion}

There is a lot of controversy among pathologists, dermatologists, clinicians and surgeons when establishing an 
seria la úlcera o enfermedad de Riga-Fede en los niños. (González, J.A.; et al. 2003) (Elzay, R. 1983). 14,15

Las causas que producen úlceras en la mucosa oral son múltiples: trauma químico, físico y térmico; agentes infecciosos (bacterias, virus, hongos, parásitos, etc.); reacciones alérgicas; neoplasias malignas y benignas; enfermedades sistémicas; trastornos psicosomáticos (aftas recidivantes, aftas mayores, etc.); desordenes linfoproliferativos (úlcera eosinofila, etc.).

En la mayoría de los estudios se postula al trauma como agente etiológico, Bhaskar y Lilly produjeron úlceras eosinófilas en forma experimental induciendo trauma con pinzas en lenguas de ratas. $^{2}$

Otros autores (incluso nosotros) afirman que esta lesión es producto de un complejo e intrincado fenómeno relacionado con desordenes linfoproliferativos (con expresión de linfocitos CD-4; CD-8; CD-3; CD-1a y ocasionalmente linfocitos CD-30+ (Ki-1) en el 70\% de los casos) y que gracias a las actuales técnicas para el estudio inmunohistoquímico con las que se cuenta en la actualidad se esta descubriendo su verdadera etiopatogenia. 6,12

La úlcera Eosinófila de la mucosa oral tanto en infantes como adultos y ancianos ha sido descrita mayormente en la lengua. Elzay en una serie de 70 casos encontró 37 en dicho órgano, y en un rango de edades de entre 1 mes de vida a 82 años. ${ }^{15}$

El papel que juegan los eosinófilos en este tipo de lesiones no esta bien establecido. Si bien se conoce que en los modelos de curación de heridas en animales, estas células normalmente producen TGF- $\alpha$ y TGF$\beta 1$ que son importantes en el proceso de curación de heridas; en el caso de la úlcera Eosinófila de la mucosa oral en humanos la síntesis de estos factores no es significativa lo que explicaría en parte el retraso de curación de estas ulceras. Sumado a esto merece destacarse el deposito de fibrina y coágulos en los vasos sanguíneos lo que interfiere aun más en el proceso cicatrizal.

En algunos casos suele curar en forma espontánea entre unos días a un año. La recurrencia suele ser frecuente y se ha descrito en reportes aislados. 10,12,13,15. Mezei y col. en su revisión encontraron recidivas en un $15 \%$ de los casos. ${ }^{11}$

El caso que presentamos ilustra las características clínicas y evolutivas, junto a su tratamiento de una lesión ulcerativa, aparentemente linfoproliferativa, que en un corto periodo de tiempo alcanzo un gran tamaño que no respondía al tratamiento con antibiótico, antivirales, etc., cuyo diagnóstico histopatológico correspondió a úlcera eosinófila de la mucosa oral.

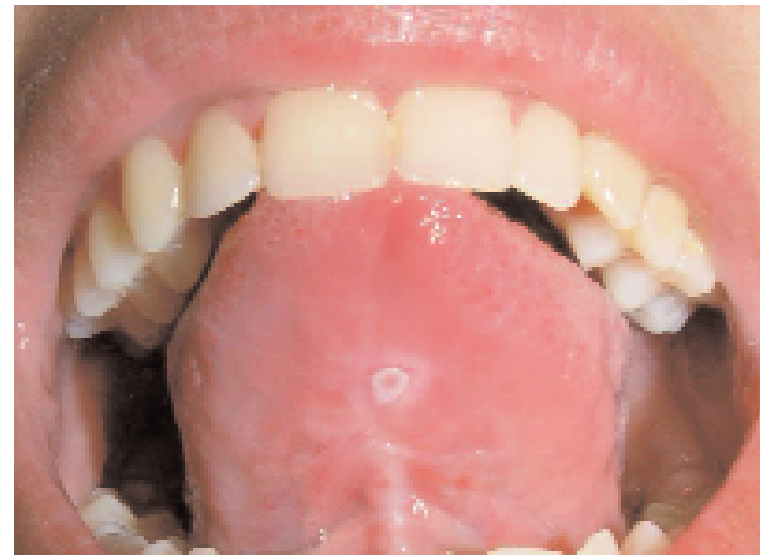

Figura 7. Remisión parcial a los 14 días. Figure 7. Partial remission after 14 years.

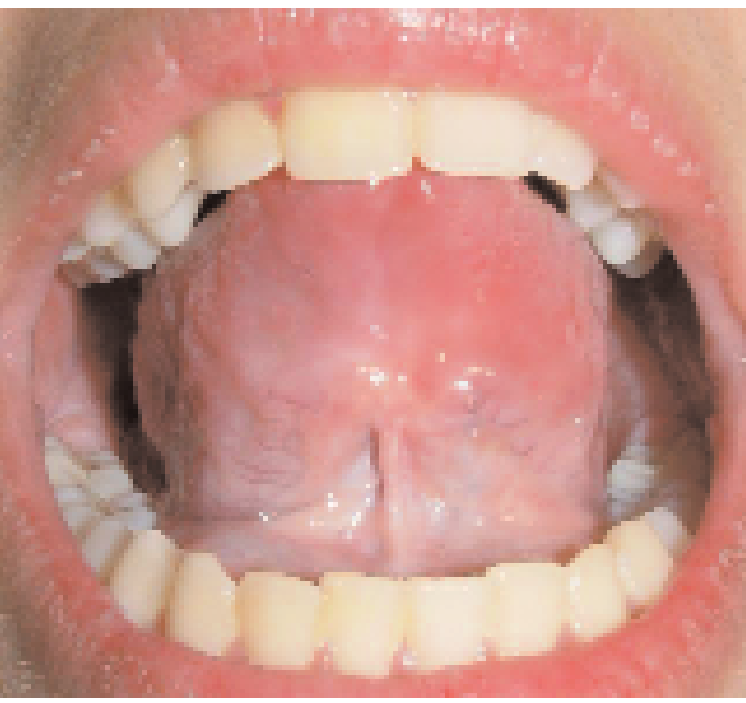

Figura 8. Remisión Total a los 45 días.

Figure 8. Total remission after 45 days. etiology and treatment for Eosinophil Ulcer of the oral mucosa.

In the majority of cases the lesion consists of an infrequent inflammatory benign process that is characterized by an ulceration with clear borders which is sometimes non painful, located on the ventral face of the tongue.

Many others give this entity a genuinely traumatic etiology and assure that in the case of adults, it is the illness or ulcer that in children is called RigaFede. (Gonzalez, Ja; et al. 2003)(Elzay, R. 1983).14,15

There are multiple causes of ulcers in the oral mucosa: Chemical, Physical and thermal trauma; infectious agents (bacteria, virus, fungus, parasites, etc.); Allergic reaction; Malignant and Benign Neoplasias; Systematic Illnesses; Psychosomatic Disorders (relapsing apathas, major apathas, etc); lympho proliferative disorders (eosinophil ulcers, etc.). In the majority of studies the etiological agent suggested is trauma. In an experiment with rats Bhaskar and Lilly created eosinophil ulcers using tweezers to create trauma in the tongue. ${ }^{2}$

Other authors (including us) assure that this lesion is the result of a complex and intricate phenomena related to lympho proliferative disorders (expressing lymphocytes $C D-4$; $C D-8 ; C D-3 ; C D-1 a$ and occasionally CD-30+ (Ki-1) in $70 \%$ of cases). Thanks to the current techniques in use available to study immuno histo-chemistry the true etiopathology is being discovered. 6,12

The oral mucosa eosinophil ulcer has been mainly described on the tongue in infants, adults and the elderly. In a series of 70 cases of patients aged 1-82 years old, Elzay found 37 cases on the tongue. ${ }^{15}$

The role that eosinophils play in this type of lesion is not well established. It is however, well known that in the healing models of animal wounds these cells normally produce TGF-. and TGF-, 1 that are important in the healing process. In the case of oral mucous eosinophil ulcer in humans synthesis of these factors it is not significant what would partially explain delayed healing of these ulcers. In addition to 

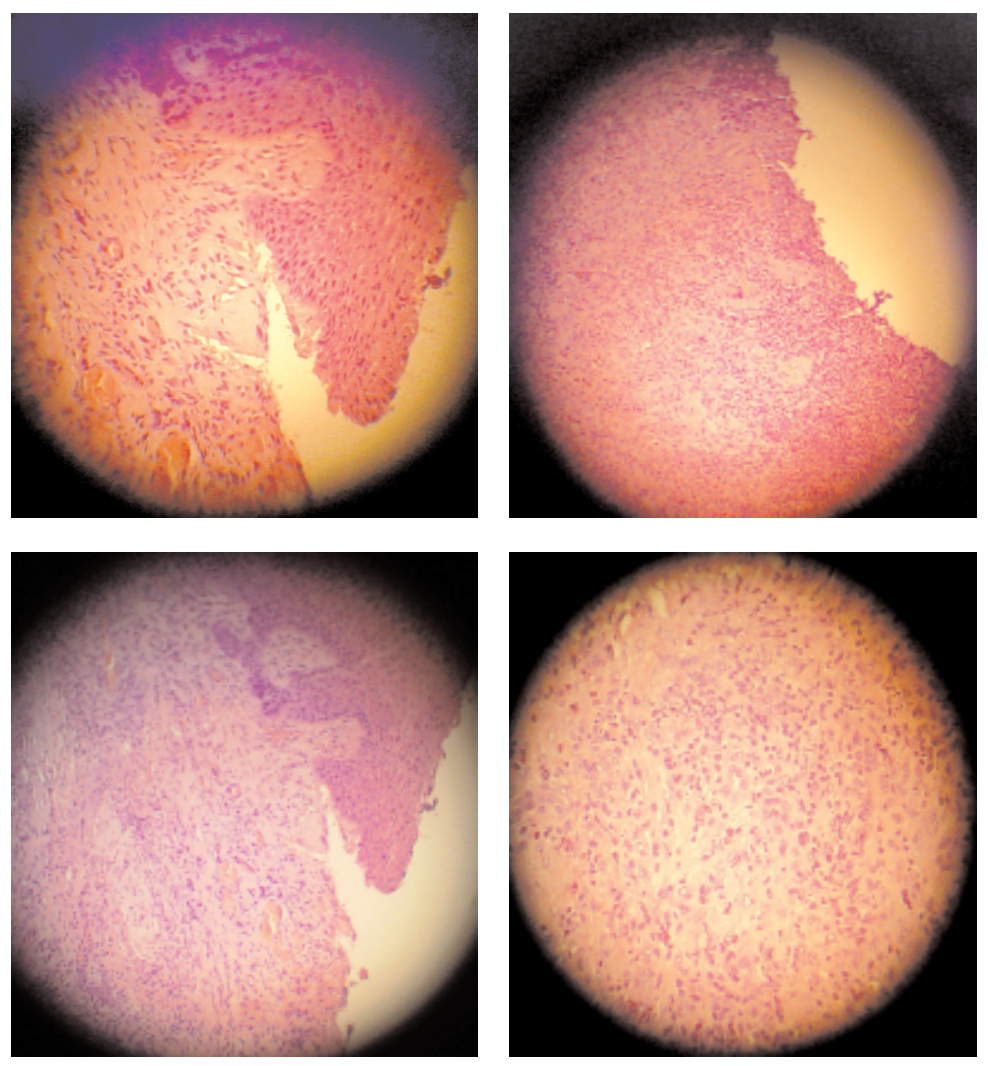

Se han propuesto numerosas alternativas terapéuticas como antibióticos, criocirugía, cirugía, corticoides, cirugía combinada con corticoterapia intralesional (Ficarra, G; et al. 1997) ${ }^{9}$ y el simple control clínico esperando la remisión espontánea. Todos los antes descriptos, han sido presentados en la literatura con resultados exitosos.

En nuestro caso optamos por la cirugía combinado con corticoterapia intralesional, obteniendo un excelente resultado.

\section{Conclusión}

Es de gran importancia el diagnóstico certero de esta patología debido a su similitud clínica con otras entidades, que responden a un tratamiento y evolución completamente diferentes.

No existe un protocolo único de tratamiento para esta lesión por sus características y por su escasa presentación. Creemos conveniente evaluar cada paciente en particular y tener en cuenta: el tamaño de la lesión, su ubicación, tiempo de evolución, edad, hábitos del paciente, recidivas, etc.; ya que en la mayoría de las publicaciones resulta tener una etiología traumática, donde bastaría con eliminar la causa y esperar su remisión espontánea. En el caso de nuestra paciente, la lesión es linfoproliferativa; por tal motivo se opto por la cirugía combinada con corticoterapia intralesional, con la cual se obtuvieron los resultados esperados. this it is important to highlight that the deposit of fibrin and blood clots in blood vessels interferes more in the scarring process.

In some cases healing takes place spontaneously between 1 day and 1 year. Recurrence is usually more frequent and has been described in isolated cases. 10,12,13,15 Mezei and col. found relapses in $15 \%$ of cases. ${ }^{11}$

The case that we present illustrates the clinical and evolutionary characteristics as well as treatment of ulcerative lesion, apparently lympho proliferative, in which in a short time becomes large in size and doesn't respond to antibiotic treatment, antivirals, etc. Its histo-pathological diagnosis corresponds to Eosinophil Ulcer of the Oral mucosa.

Many therapeutic alternatives have been proposed, for example antibiotics, cryosurgery, corticoids, surgery combined with intra lesional cortico therapy (Ficarra, G; et al. 1997) $)^{9}$ and the simple clinical control of waiting for spontaneous remission. All of the above described have been presented in the literature with successful outcomes.

In our case we chose combined surgery and intra lesional cortico therapy which gave us a positive result.

\section{Conclusion}

It is very important to get an accurate diagnosis of this pathology. Mainly because of its clinical similarity to other entities that respond to treatment and evolution very differently.

Due to this lesions characteristics and scarce presence, when it comes to treatment there is not one specific protocol. We think it is convenient to evaluate each patient keeping in mind: the size of the lesion, its location, time of evolution, age, habits of patient, relapses, etc; knowing that in the majority of the publications it ends up having etiology of trauma where it would be enough to eliminate the cause and wait for spontaneous remission. In the case of our patient the lesion is lympho proliferative, because of this we chose combined surgery and intra lesional cortico therapy and the results were positive. 


\section{Bibliografía}

1. Publicación de la Sociedad Argentina de Dermatología "Enfermedades eosinofílicas cutáneas". Dermatología Argentina. 2002;4:82-196.

2. Bhaskar, S; Lilly, G. Traumatic granuloma of de thongue (human and experimental). Oral Surg, Oral Med, Oral Patol. 1964;18:206-18.

3. Antonio Guzmán, Gloria Mendoza "Dientes natales y Enfermedad de Riga-Fede". Dermatol pediatr lat 2005;3:152-7.

4. Liliana Vizcaya Barraza, J.M. Nuñez Martinez, J.M. Branzo Fernandez, Reynaldo Falcon Escobedo. "Úlcera eosinofica de lengua". ADM 2003;13:36-9.

5. Wilson A. Delgado, Italo Funes. "Úlcera eosinofílica de lengua". Rev. Estomatol Herediatra 2003;13:36-9.

6. Segura S, Romero D, Mascaro JM Jr, Colomo L, Ferrando J, Estrach T. "Eosinophilic ulcer of the oral mucosa: another histological simulator of CD30+ lymphoproliferative disorders". Br J Dermatol. 2006;155:460-3.

7. García M, Pagerols X, Curco N, Tarroch X, Vives P. "Eosinophilic ulcer of the oral mucosa: 11 cases". Ann Dermatol Venereol. 2002;129:8713.
8. Melgarejo Moreno PJ, Hellin Meseguer D, Ruiz Macia JA. "Eosinophilic ulcers of the tongue as an adverse reaction to carbamazepine" An Otorrinolaringol Ibero Am. 1998;25:167-71.

9. Ficarra G, Prignano F, Romagnoli P. "Traumatic eosinophilic granuloma of the oral mucosa: a CD30+(Ki-1) lymphoproliferative disorder?" Oral Oncol. 1997;33: 375-9.

10. Velez A, Alamillos FJ, Dean A, Rodas J, Acosta A. "Eosinophilic ulcer of the oral mucosa: report of a recurrent case on the tongue" Clin Exp Dermatol. 1997; 22:154-6.

11. Mezei MM, Tron VA, Stewart WD, Rivers JK. "Eosinophilic ulcer of the oral mucosa" J Am Acad Dermatol. 1995;33:734-40.

12. Mofty SK, Swanson PE, Wick MR, Miller AS. "Eosinophilic ulcer of the oral mucosa. Report of 38 new cases with immunohistochemical observations" Oral Surg Oral Med Oral Pathol. 1993;75:716-22.

13. Doyle JL, Geary W, Baden E "Eosinophilic ulcer" J Oral Maxillofac Surg. 1989;47: 349-52.

14. Gonzales JA, Rivas MA, Medina MA, Ocaña, J. Úlcera eosinófila de la Mucosa Oral. Med cutan Iber Lat Am. 2003:31:213-4.

15. Elzay R. Traumatic ulcerative granuloma with estromal eosinophilia (Riga-Fededisease and traumatic eosinophilic granuloma). Oral Surg 1983;55:497-506. 